$\underline{\text { Research Article }}$

\title{
The Effect of Vitamin E Administration on Histopathological Description of Mice (Mus musculus) Liver Exposed to Mercuric Chloride
}

\section{Pengaruh Pemberian Vitamin E terhadap Gambaran Histopatologi Hati Mencit (Mus musculus) yang Terpapar Merkuri Klorida $\left(\mathrm{HgCl}_{2}\right)$}

\author{
Acivrida Mega C, Intan Febiola A
}

Department of Parasitology STIKES RS Anwar Medika Sidoarjo

\begin{abstract}
Mercuric chloride may deposit in the liver with a high metabolic rate, delivering substrate and energy from one metabolic system to others, and processing and synthesizing various substances transported to the body. This research aimed to determine the effect of vitamin E administration on liver histopathology of mice (Mus musculus) exposed to mercuric chloride and to determine the histopathological image of the liver. Samples were grouped into PO (not treated), P1 (mercuric chloride $50 \mathrm{mg} / \mathrm{kgBW}$ ), P2 (mercuric chloride 50mg/kgBW + vitamin E 50mg/kgBW), P3 (mercuric chloride $50 \mathrm{mg} / \mathrm{kgBW}+$ vitamin $E 100 \mathrm{mg} / \mathrm{kgBW}$ ), and $P 4$ (mercuric chloride $50 \mathrm{mg} / \mathrm{kgBW}+$ vitamin E 150mg/kgBW) using experiment laboratory method. The data were analyzed using the One Way ANOVA to recognize the difference in changes in vitamin $E$ on hepatocytes damage exposed to mercury chloride. The results showed mercury chloride damages hepatocyte, while the administration of vitamin $E$ as a whole showed changes in hepatocyte repair. The optimal dose for hepatocyte repair is $100 \mathrm{mg} / \mathrm{kgBW}$.
\end{abstract}

Keywords: Histopathology, liver, mercury, mice, vitamin $E$

\begin{abstract}
ABSTRAK
Merkuri klorida dapat mengendap di organ hati dengan laju metabolisme yang tinggi, memberikan substrat dan energi dari satu sistem metabolisme ke sistem yang lain, mengolah dan mensintesis berbagai zat yang diangkut ke tubuh. Penelitian ini bertujuan untuk mengetahui pengaruh pemberian vitamin E terhadap histopatologi hepar mencit (Mus musculus) yang terpapar merkuri klorida dan untuk mengetahui gambaran histopatologi hepar. Sampel dikelompokkan menjadi P0 (tidak diberi perlakuan), P1 (merkuri klorida 50mg/kgBB), P2 (merkuri klorida 50mg/kgBB + vitamin E $50 \mathrm{mg} / \mathrm{kgBB}$ ), P3 (merkuri klorida 50mg/kgBB + vitamin E 100mg/kgBB), and P4 (merkuri klorida 50mg/kgBB + vitamin E $150 \mathrm{mg} / \mathrm{kgBB}$ ) $d$. Data dianalisis menggunakan One Way ANOVA untuk mengetahui perbedaan perubahan vitamin $\mathrm{E}$ pada kerusakan hepatosit yang terpapar merkuri klorida. Hasil penelitian menunjukkan bahwa merkuri klorida memiliki efek kerusakan hepatosit sedangkan pemberian vitamin E secara keseluruhan menunjukkan adanya perubahan perbaikan hepatosit. Dosis yang optimal dalam perbaikan hepatosit adalah $100 \mathrm{mg} / \mathrm{kgBB}$.
\end{abstract}

Kata Kunci: Hati, histopatologi, mencit, merkuri, vitamin E

Correspondence: Acivrida Mega C. Department of Parasitology STIKES RS Anwar Medika Sidoarjo, Raya KM 33 Jalan Bypass Krian, JI. Parengan, Semawut, Balongbendo, Kec. BalongBendo, Kabupaten Sidoarjo, Jawa Timur 61262 Tel. (031) 99892096 Email: acie.vrida@gmail.com

DOI: http://dx.doi.org/10.21776/ub.jkb.2020.031.01.4 


\section{INTRODUCTION}

One of the heavy metals that is often found is mercury, especially mercuric chloride. Mercury is heavy metal grouped among Cadmium ( $\mathrm{Cd}$ ) and Lead $(\mathrm{Pb})$. Mercury penetrates the body tissues through several ways, such as respiratory tract, digestive system, and skin. The metal enters through the digestive system by passing through the respiratory tract so that it is carried by the blood and is circulated throughout the body. The danger caused by the mercury compound is the emergence of organ damages, especially the liver (1). Liver is an organ located in the right upper quadrant of the abdomen under the diaphragm and protected by ribs. The liver functions as the body's metabolic center, digestion aids, and toxic-substances protection through the detoxification process. Most of the chemicals or drugs that enter through the digestive system will pass through the liver as the central metabolic organ. Therefore, the liver will suffer damage if the exposure continues (2).

A previous study (3) showed that an oral administration of mercury caused changes in histocytes of Wistar rats. An increase in mercury absorbed leads to more severe damages that explain the metal toxicity in the liver. Mercury toxicity directly affects enzyme activity, inhibits trace mineral absorption, binds the synthesis of protein structures, alters calcium homeostasis, and decreases the body antioxidant properties. Metal toxicity symptoms such as abdominal pain, vomiting, and bloody diarrhea are due to increased cell necrosis in the intestinal mucosa and may lead the sufferer to death. Mercury chloride administration showed a change in the color of the liver with white spots, which means the liver was damaged macroscopically. Hence, antioxidants are needed.

Antioxidants are substances that the body needs to neutralize and prevent the damage caused by free radicals. Antioxidant intake can be obtained from vitamins, such as vitamin $\mathrm{E}$, that can prevent oxidation and peroxidation of unsaturated fatty acids and membrane phospholipids. Previous research (4) stated that vitamin E can improve the histological damage of the liver and pancreas in white rats due to dexamethasone administration. Another study (5) also mentioned that vitamin E could reduce SGOT and SGPT in white Wistar rats after exposure to lead because vitamin $\mathrm{E}$ prevents damage to the hepatocyte membrane which will prevent SGOT and SGPT enzymes leak out into the bloodstream. Therefore, research is needed to determine the effect of vitamin $\mathrm{E}$ administration on the histopathological description of the liver of mice after exposure to mercury chloride.

\section{METHOD}

This research was conducted using experimental laboratory with a post-test only control group design to determine the effect of vitamin $\mathrm{E}$ administration on the liver of mice exposed to mercury. The samples used were 25 mice (Mus musculus) aged 2-3 months weighed 25-35 grams and were grouped into P0 (not treated), P1 (mercuric chloride $50 \mathrm{mg} / \mathrm{kgBW}$ ), P2 (mercuric chloride $50 \mathrm{mg} / \mathrm{kgBW}+$ vitamin E 50mg/kgBW), P3 (mercuric chloride $50 \mathrm{mg} / \mathrm{kgBW}$ + vitamin $\mathrm{E} 100 \mathrm{mg} / \mathrm{kgBW})$, and $\mathrm{P4}$ (mercuric chloride 50mg/kgBW + vitamin E 150mg/kgBW) (5). Mercuric chloride and vitamin E were given orally for 21 days at the Biology Laboratory of STIKES Anwar Medika Hospital. Then, the samples were sacrificed, and the livers were taken to make histopathological preparations using HE (Hematoxylin-eosin) staining at the Anatomy Pathology Laboratory, Airlangga University. Afterward, observation on hepatocytes undergoing parenchymous degeneration was conducted; hydropic degeneration and necrosis $(d p+d h+n e)$ were done in five field of view with $400 x$ magnification using a binocular microscope. The hepatocyte damage score was assessed using Manja Roenigk score. In each field, twenty hepatocyte cells were counted and multiplied by each cell damage category score (Table 1). The average scores from all five field of view in each sample were calculated (3). The difference of hepatocyte damage score was analyzed using One Way ANOVA followed by post hoc LSD test.

Tabel 1. The scoring of Manja Roenigk (3)

\begin{tabular}{|c|c|c|c|}
\hline \multicolumn{4}{|c|}{ NoDamageratఠcoreNote } \\
\hline \multicolumn{4}{|c|}{ 1Norm畔Hepatocytesareround,the cytoplasm } \\
\hline & & & $\begin{array}{l}\text { is } \mathbf{c o} \text { purple, and the cell } \\
\text { membrane is not damaged }\end{array}$ \\
\hline 2 & $\begin{array}{l}\text { Parenchymal } \\
\text { degeneration }\end{array}$ & 2 & $\begin{array}{l}\text { Hepatocytes are swelling, cytoplasm is } \\
\text { turbid, andaga les appear in the } \\
\text { cytoplasm }\end{array}$ \\
\hline 3 & $\begin{array}{l}\text { Hydrophical } \\
\text { degeneration }\end{array}$ & 3 & $\begin{array}{l}\text { Hepatocytes undergo vacuolization in } \\
\text { the ct/ pl as and are larger in size } \\
\text { due to an icreas e in fluid }\end{array}$ \\
\hline 4 & Necrosis & 4 & $\begin{array}{l}\text { Hepatocytes undergo shrinkage in the } \\
\text { nucleus (pisn) is, break into } \\
\text { fragments k y (kareo i sis), lysis } \\
\text { (karyolysis), cell membranes have } \\
\text { unclear boundar ies }\end{array}$ \\
\hline
\end{tabular}

\section{RESULTS}

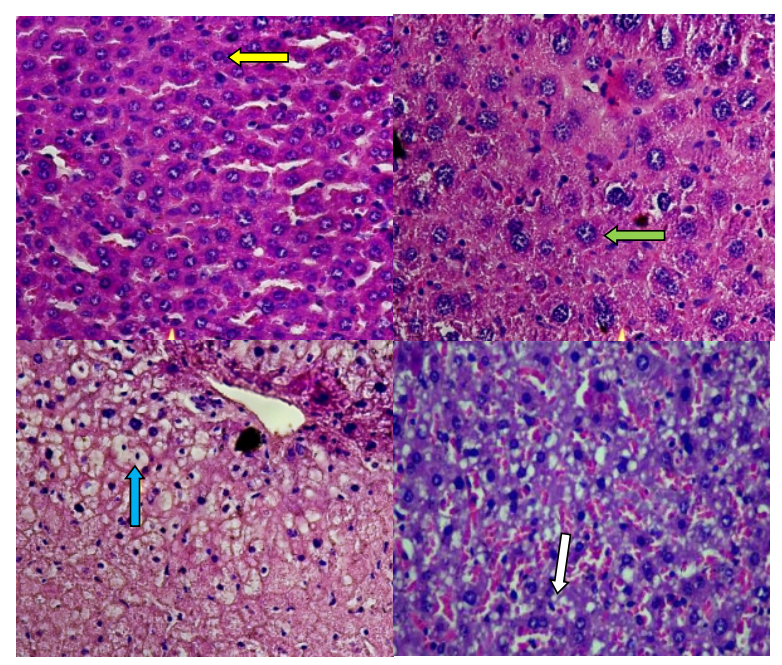

Figure 1. Observation results of hepatocyte damage types of HE staining HE magnification 400x

Note: yellow arrows indicate normal hepatocytes, green arrows indicate parenchymatic degeneration hepatocytes, blue arrows indicate hydropic degeneration, white arrows indicate necrotic hepatocytes

The histopathology examination revealed normal hepatocytes in the control group (Figure 1). Normal 
hepatocytes are characterized by round hepatocytes, intact cytoplasm, purple in color, and undamaged cell membranes (6). In the P1 group that was only given mercury chloride, the necrosis was quite high. Necrosis is characterized by shrinking nuclei (picnosis), splitting into fragments (karyokinesis), lysis (karyolysis), and having unclear cell-to-cell boundaries (7). So, the average score becomes 237 which is the highest score. Likewise, the results of P2, P3, and P4 groups which are the treatment groups given mercury chloride and vitamin $\mathrm{E}$ at a dose of $50 \mathrm{mg} / \mathrm{kgBW}, 100 \mathrm{mg} / \mathrm{kgBW}$, and $150 \mathrm{mg} / \mathrm{kgBW}$, respectively, showed hepatocyte. Only a few experience necrosis. Before the damaged hepatocytes undergo reversible changes called parenchymous degeneration and hydropic degeneration, parenchymal degeneration is characterized by cell swelling, cytoplasmic opacification, and granules appearing in the cytoplasm. A paler visible cytoplasmic color characterizes hydropic degeneration. Vacuoles are swelling because they are filled with fluid and are larger (8).

The results found hepatocyte damage in all groups, but the average damage score was different. The highest average hepatocyte damage score was P1 (mercuric chloride $50 \mathrm{mg} / \mathrm{kgBW}$ ) as much as 237 , while the lowest hepatocyte damage score was PO (not treated) as much as 111.8. Therefore, the higher the mercuric chloride dosage, the less normal the hepatocyte score.

Table 2. Average scores of rats hepatocyte

\begin{tabular}{lrrc}
\hline Group & $\begin{array}{c}\text { tblepa } \\
\text { Damage }\end{array}$ & $\begin{array}{c}\text { Significance Score of } \\
\text { One Way ANOVA }\end{array}$ \\
\hline P0 & P=0.00 & 111,8 & \\
P1237 & & & \\
P2195 & &, 6 & \\
P3182 & &, 8 & \\
P4213 & &, 6 & \\
\hline
\end{tabular}

Table 3 shows that there are significant differences between $\mathrm{PO}$ (not treated) and the four intervention groups (P1, P2, P3, P4), inferring that mercury chloride has an effect on hepatocyte damage for 21 days. The administration of vitamin $\mathrm{E}$ at a dose of $100 \mathrm{mg} / \mathrm{kgBW}$ shows the effect of hepatocyte repair due to mercuric chloride exposure, while the doses of $50 \mathrm{mg} / \mathrm{kgBW}$ and $100 \mathrm{mg} / \mathrm{kgBW}$ do not show improvement.

Table 3. Post Hoc LSD Test for Each Group

\begin{tabular}{rrrrrr}
\hline & P0 & \multicolumn{1}{c}{ P1 } & \multicolumn{1}{c}{ P2 } & \multicolumn{1}{c}{ P3 } & \multicolumn{1}{c}{ P4 } \\
\hline P0 & 0,00 ${ }^{*}$ & $0,000^{*}$ & 2 & $0,006^{*}$ & $0,000^{*}$ \\
P1 & 0,000* & - & 0,071 & $0,022^{*}$ & 0,313 \\
P2 & 0,002* & 0,071 & - & 0,571 & 0,396 \\
P3 & 0,006* & $0,022^{*}$ & 0,571 & - & 0,164 \\
P4 & 0,000* & 0,313 & 0,396 & 0,164 & - \\
\hline
\end{tabular}

Note: * there are significant differences $(P<0,05)$

\section{DISCUSSION}

This study aims to determine the effect of vitamin $E$ administration on the liver of mice exposed to mercury chloride for 21 days.

The highest average damage score was found in the positive control group that shows a lot of necrotic hepatocytes. Necrosis is a dead cell that shows morphological changes in living tissue and is caused by a progressive reduction of enzyme activity in cells affected by free radicals. Especially, free radical triggers come from heavy metals, one of which is mercury chloride (9). Research results (10) mentioned mercury chloride is a dangerous heavy metal with a high degree of poisoning and is easily metabolized by the body, especially the liver. Prior to the necrosis stage, cells undergo a reversible morphological change called degeneration. This stage is divided into two, namely parenchymatic degeneration and hydropic degeneration. Parenchymal degeneration is the mildest degeneration because fat begins to accumulate in the liver parenchyma while hydropic degeneration is the last degeneration due to intracellular accumulation, which is more severe and will lead to the necrosis stage (11). The lowest average score is $\mathrm{PO}$ because there are quite a lot of normal hepatocytes. Hepatocyte damage in the negative control group is caused by natural metabolism in the body of mice. Both control group has no additional antioxidant (vitamin E), so antioxidants from the inside cannot inhibit the development of natural free radicals that occur in the body of mice (12).

The result shows that the administration of mercury chloride for 21 days causes hepatocyte damage because mercury chloride toxicity has the potential to inhibit the work of enzymes that interfere metabolism in the liver because it is sensitive to toxic substances (13). The administration of vitamin $E$ for 21 days at a dose of $100 \mathrm{mg} / \mathrm{kgBW}$ has an optimal hepatocyte repair effect due to exposure to mercury chloride. Whereas doses of $50 \mathrm{mg} / \mathrm{kgBW}$ and $200 \mathrm{mg} / \mathrm{kgBW}$ have not caused any improvement effect. Vitamin E dose of $50 \mathrm{mg} / \mathrm{kgBW}$ has not been able to ward off the toxicity of strong mercury chloride due to oxidative stress factors where the capacity of vitamin $E$ is still unable to neutralize the presence of mercury chloride due to the higher intensity of mercury chloride (14). While the dose of $200 \mathrm{mg} / \mathrm{kg}$ does not cause an optimal repair effect because vitamin $E$ has a prooxidant effect (15). When vitamin E is consumed at high dosages, it will encourage oxidation of free radicals, thus will inhibit the ability to protect cells as antioxidants (16).

This study concludes that the administration of mercury chloride for 21 days induces hepatocyte damage, and the administration of vitamin $E$ shows a decrease in the hepatocyte damage at the optimum dosage of $100 \mathrm{mg} / \mathrm{kgBW}$.

\section{ACKNOWLEDGMENT}

I would like to express my gratitude to STIKES Anwar Medika Hospital and the Anatomy Pathology Laboratory of Airlangga University for helping and supporting this research.

\section{REFERENCES}

1. Yusnia S and Syarief SH. Peranan Nanogold terhadap Organ Hati Mencit (Mus Musculus) yang Terpapar 
2. Taufikurohmah T, Winarni D, Baktir A, Sanjaya IGM, and Syahrani A. Histology Study: Pre-Clinic Test of Nanogold in Mus Musculus Skin, at Fibroblast Proliferation and Collagen Biosynthesis. Chemistry and Materials Research. 2013; 3(5): 55-60.

3. Taufikurohmah T, Baktir A, Sanjaya IGM, and Syahrani A. TEM Analysis of Gold Nanoparticles Synthesisin Glycerin: Novel Safety Materials in Cosmeticsto Recovery Mercury Damage. Research Journal of Pharmaceutical, Biological and Chemical Sciences. 2014; 5(1): 397-407.

4. Insani A, Suri S, and Berata IK. Gambaran Histopatologi Hati dan Pankreas Tikus Putih yang diberikan Deksametason dan Vitamin E. Indonesia Medicus Veterinus. 2015; 4(3): 228-237.

5. Tatukude P, Loho L, and Lintong P. Gambaran Histopatologi Hati Mencit Swiss yang Diberi Air Rebusan Sarang Semut (Mymercodia Pendans) Paska Induksi dengan Carbon Tetraklorida (CCL4). Jurnal e-Biomedik (eBM). 2014; 2(2): 453-466.

6. Hidayat A, Chrisjianti W, and Marianti. Pengaruh Vitamin E terhadap Kadar SGPT dan SGOT Tikus Putih Galur Wistar yang Dipapar Timbal. Unnes Journal of Life Science. 2013; 2(1): 16-21.

7. Tamad FSU, Hidayat ZS, and Sulistyo H. Gambaran Histopatologi Tikus Putih Setelah Pemberian Jinten Hitam Dosis $500 \mathrm{mg} / \mathrm{kgBB}, 1000 \mathrm{mg} / \mathrm{kgBB}$, dan $1500 \mathrm{mg} / \mathrm{kgBB}$ Selama 21 Hari (subkronik). Mandala of Health. 2011; 5(3): 1-5.

8. Sari WN, Saebani, and Dhanardhono T. Pengaruh Pemberian Butylated Hydroxytoluene (2,6-Di-TertButyl-4-Methylphenol) per Oral Dosis Bertingkat terhadap Gambaran Histopatologi Hepar Tikus Wistar. Jurnal Kedokteran Diponegoro. 2018; 7(2): 1344-1357.

9. Clarkson TW and Magos L. The Toxicology of Mercury and Its Chemical Compounds. Critical Reviews in Toxicology. 2006; 36(8): 609-662.

10. Hastuti US. Pemberian Patulin Menyebabkan Kerusakan Struktur dan Ultra Struktur Hepatosit Mencit. Jurnal Kedokteran Brawijaya. 2014; 28(2): 101-106.

11. Ichsantya B, Berata IK, Samsuri, and Merdana IM. Pengaruh Suplementasi Vitamin E terhadap Efek Samping Deksametason pada Paru Tikus Putih Jantan. Buletin Veteriner Udayana. 2017; 9(2): 187-194.

12. Muliartha I, Sriwahyuni E, and Yuliawati. Pemberian Kombinasi Vitamin C dan E Per Oral Memperbaiki Kerusakan Hepar Akibat Paparan Rokok Kretek Sub Kronik. Jurnal Kedokteran Brawijaya. 2009; 25(1): 2327.

13. Wiguna A, Hadi, dan Amarwati S. Pengaruh Pemberian Merkuri Per Oral terhadap Gambaran Histopatologis Ginjal Tikus Wistar. Jurnal Kedokteran Diponegoro. 2016; 5(4): 403-411.

14. Roziana, Subagio HW, Suharsono, and Widyastiti NS.

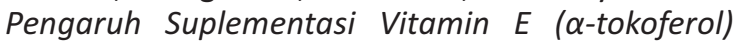
terhadap Kadar Gamma Glutamil Transferase (GGT) dan Kadar Nitric Oxide (NO) pada Tikus (Studi pada Tikus Rattus Novergicus Strain Wistar Jantan terpapar Inhalasi Uap Benzene). Jurnal Gizi Indonesia. 2015; 3(2): 73-79.

15. Johan J, Hadi, and Amarwati S. Pengaruh Pemberian Merkuri Per Oral terhadap Gambaran Histopatologi Liver Tikus Wistar. Jurnal Kedokteran Diponegoro. 2017; 6(2): 673-681.

16. Nursheha A dan Febrianti N. Pengaruh Ekstrak Daun Cincau Hijau (Cyclea Barbata Miers) terhadap Gambaran Histopatologik Hepar Mencit (Mus musculus) yang Diinduksi MSG sebagai Sumber Belajar Biologi SMA Kelas XI. Jupemasi-PBIO. 2015; 1(2): 198-203 